\title{
Can we fly less? Evaluating the 'necessity' of air travel
}

\begin{abstract}
Air travel is often justified as 'necessary' or 'unavoidable', in the sense that trips have purpose and value. Yet it is evident that people travel for reasons that may include forced and voluntary movement, with motives ranging from visiting friends and family, to leisure, or business. In light of the challenge to decarbonise transport, and the need to reduce greenhouse gas emissions, this paper discusses the perceived necessity of flight from individual and societal perspectives, while considering moral and economic viewpoints. It suggests that travel motives have different degrees of 'urgency', and that the 'necessity of flight' cannot be generalized. To empirically test this hypothesis, we used mixed methods to examine the perspectives of 29 international students at Lund University, Sweden on the perceived importance of their flights $(n=587)$ over a six-year period (2012-2017). Results show that the value associated with individual flights depends on flight motive, experience, life stage, or situational factors. Almost half of the flights made (48\%) lack importance. Implications are discussed in the context of climate policy and the future development of the aviation system.
\end{abstract}

Key words: Aviation, climate policy, induced demand, Paris Agreement, travel motives.

\section{Introduction}

Aviation is increasingly in conflict with societal goals to limit climate change and challenges related to air pollution, noise, and infrastructure expansion (Finance and Trade Watch 2016; Gössling and Upham 2009). While aviation advocates have frequently underlined the importance of air traffic for GDP growth and employment, it is equally clear that increasing dependence on air travel contradicts several of the United Nations' Sustainable Development Goals (UN 2015), such as Responsible Production and Consumption (Goal 12) and Climate Action (Goal 13), and undermines the Paris Agreement (Scott et al. 2016). These problems have become ever more pressing under scenarios of continued growth of air travel, as anticipated by industry actor groups. For example, the International Civil Aviation Organisation projects that emissions will grow by a factor of 2.8-3.9 between 2010 and 2040 (ICAO 2016). Neither technology innovations, the aviation sector's own strategies, nor market-based measures can be expected to resolve this situation (Lyle 2018; Markham et al. 2018; Peeters et al. 2016). A central question for aviation is thus whether people should, or could, fly less. This pressing question received global attention when it was raised by the Fridays for Future movement and the mainstream media’s reporting on 'flight shame' in early 2019 (e.g. Evening Standard 2019). The Guardian (2019, no page) summarized the dilemma:

So when scientists say that we must make "rapid, unprecedented change" to our lifestyles to avoid climate catastrophe, and pinpoint flying as the most destructive form of travel, the questions mount: Is there such a thing as a right to fly? Is selfsacrifice necessary? Can you fly with a conscience? Are "love miles" to see family or friends OK?

It is generally established that people travel for a wide range of reasons, such as business, to visit friends and family, to relax or escape, to experience novelty, or self-develop (Pearce and Lee 2005). Most of the longer distance trips involve aircraft, and an estimated $57 \%$ of all international arrivals are now by air (UNWTO 2018). Against this background, aviation organisations maintain two main discourses. The first sustains the notion that air travel is a 'norm', involving large parts of the global population. While this is communicated by highlighting large global passenger numbers (e.g. IATA 2018), it obscures the reality that most 
flights are taken by the most privileged social classes in the most affluent societies. The second discourse affirms that all air travel is valid, in the sense that flying is socially desirable and morally warranted, and that individual motivations for air travel are rational and justifiable, with air travel providing economic value (IATA 2018; UNWTO 2018). This latter discourse is perhaps best understood in terms of the absence of any critical debate on air travel motivations among supranational organisations such as United Nations Environment Programme (UNEP), UN World Tourism Organisation (UNWTO), World Tourism and Travel Council (WTTC), International Air Transport Association (IATA), or International Civil Aviation Organisation (ICAO).

The low carbon challenge underlying the Paris Agreement demands a critical discussion of the discourses surrounding air travel. This article seeks to examine the 'necessity of flight', that is, the question of whether all air travel is perceived to be of equal importance, in order to ascertain the types of flight that might be more easily reduced. For this purpose, motivations for air travel are discussed from moral and economic perspectives. Moral concern demands reconsideration of energy-intense activities and lifestyles against the background of carbon inequality and the Sustainable Development Goals (Oxfam 2015; UN 2015). Economic perspectives are characterized by utility values assigned to air travel; that is, the money people are willing to spend in order to fly. Both moral concern and economic value can be discussed from societal and individual perspectives. The paper conceptualizes these interrelationships to then present the results of a mixed methods empirical study, in which personal value associations with air travel are analysed out of personal, retrospective views on the importance of flight.

\section{Background}

Flying as a social norm

Air travel is regularly presented as a social norm, specifically by aviation organisations and airlines. This creates and fosters various discourses and mechanisms designed to strengthen a social norm of flying, for example based on passenger statistics, support of cheap flights, traveller self-promotion through frequent flier programmes, as well as wider issues of economic development, employment or intercultural understanding. A selection of discourses is presented in the following, illustrating how such social norms are presented. Importantly, discourses conceal that most people never fly, or fly very rarely (Peeters et al. 2006; Gössling et al. 2009a,b).

Large passenger numbers and notions of frequent air travel are often highlighted to suggest that flying is a mass activity. According to the International Air Transport Organisation (IATA), an estimated 4.1 billion passengers were counted worldwide in 2017, and in this year, "the average citizen flew [...] once every 22 months.” (IATA 2018: no page). The statement seems to suggests that " 4.1 billion passengers" correspond to the flying population, which implies an activity that involves a significant share of humanity. However, passenger numbers represent individual flights. As virtually all travellers will return from their destination, two individual flights usually represent one trip. Where travellers move through hubs, or visit multiple destinations, the number of individual flights involved in one trip will be even larger. It is also important to note that there is no such thing as an "average citizen" in aviation, as flight activity is highly skewed between individual travellers: Frequent fliers may participate in hundreds of trips per year (e.g. Lassen 2006; Gössling et al. 2009b). Research thus suggests that a small number of highly frequent fliers account for a large share of total global air travel (Brand and Boardman 2008; Lassen 2006; Gössling et al. 2009a). 
Even in wealthy countries, many citizens do not fly in any given year. For example, DEFRA (2009) reported that of the UK population 16 years or older, 59\% had not flown in 2009. In Germany, 23\% of the population did not travel anywhere for their holidays in 2014, and of those travelling, more than half did not fly (Gössling et al. 2017a). In countries of the global South, it is likely that large parts of the population never fly, as a result of financial constraints, visa limitations, or the unavailability of air travel opportunities. As Sheller (2016: 15) emphasizes:

Mobility may be considered a universal human right, yet in practice it exists in relation to class, racial, sexual, gendered, and disabling exclusions from public space, from national citizenship, and from the means of mobility at all scales. These barriers to access and controls over mobility are implemented via formal and informal policing, borders, gates, passes, clothing, rules, and surveillance systems that limit the right to move [...]

While people in many developing countries face such barriers, affluent countries have extended significant financial support to the manufacturers of aircraft, infrastructure providers, airlines and airports (Gössling et al. 2017b). Subsidies to the aviation system can take the form of grants, equity infusions, loans and loan guarantees, public service obligations, reduced taxes or tax exemptions as well as hidden subsidies such as reduced infrastructure fees or monopoly rights. As transport demand is essentially a function of cost (Zahavi 1974; Schafer and Victor 2000), air travel also grows because it is subsidized, thus creating the basis for a social norm of cheap flight. This is perhaps best illustrated by the example of low-cost carriers, which continue to offer tickets at a price that is below or equivalent to the cost of fuel and handling fees ${ }^{1}$, and usually far lower than the equivalent cost of train travel.

Contrary to popular belief, the introduction of low-cost airlines in the 1990s did not result in an increased diversity of people travelling (i.e. by increasing access to air travel for those on lower incomes), but increased the amount of air travel undertaken by the highest income groups. This was evidenced by Banister (2018: p.134) who found that a disproportionate amount of air travel across all airports in England and Wales is carried out by the 8\% of those in the highest personal income group (>€65,000). These inequalities in flight activity were also reflected in UK household travel survey data, which reported that over a 7-year period (2006-2012) 54.8 per cent of those surveyed made no flights, yet at the other end of the scale 3.4 per cent of respondents accounted for 30 per cent of all flights, with 5 or more international flights (ibid).

Social norms are furthermore reinforced through advertisement, in which airlines appeal motivations for travel including shopping, relaxation, or experiences; and within space-time constraints regarding the destinations offered, the length-of-stay suggested, or the timing of the flight during the year. Frequent flier programmes often complement offers in attempts to bind customers closely to airlines (Ostrowski et al. 1993). This may include rewards for frequent mobility, or opportunities for non-flight consumption to be turned into air travel, for example through purchases with credit cards issued by airlines (Toh et al. 1991). Advertisement as well as frequent flier programmes consequently reinforce norms of frequent air travel and, ultimately, notions of entitlement. This is made tangible in socially structured airport

\footnotetext{
${ }^{1}$ As an example, Ryanair offered, in May 2019: Stockholm Skavsta (Sweden) to Karpathos airport (Malta), 2704 $\mathrm{km}$ one way, for the price of 32 Euro, as well as Stockholm Skavsta to Bremen (Germany), 815 km one way, for the price of 4.80 Euro. At an estimated fuel use of $3.5 \mathrm{~L}$ per $100 \mathrm{~km}$, and a world market price of $€ 0.3 / \mathrm{L}$, the prices charged can be compared to the estimated actual fuel use/cost of $95 \mathrm{~L} / € 29$ (Skavsta-Malta) and $28 \mathrm{~L} / € 8$ (Skavsta-Bremen).
} 
environments, in which only selected air travellers may access "Senator Lounges" or similar spaces restricted to a hierarchy of the most frequent fliers (Young et al. 2014).

Because air travel is associated with opportunity, it is interpreted as a signifier of social standing (Urry 2011). More recently, social networking sites have made it possible to efficiently turn air travel into network- and social capital (Germann-Molz 2012; Gössling and Stavrinidi 2016). This subsequently has resulted in Instagram in particular becoming a key site for travel communication by influencers and travellers (Gretzel 2018). "Instagrammability" (The Independent 2017) describes the search for locations or experiences that can be used for selfpromotion. This is a process in which social norms of desirable lifestyles are created for which frequent mobility is a precondition (Gössling and Stavrinidi 2016; Gretzel 2017).

The examples above illustrate how air travel is supported by and framed within discourses and practices underlining the social and individual desirability of flight, that is, how it is maintained as a social norm. At the same time, there is a notable absence of public discussion on the legitimacy of flight, the moral valence of different motives for air travel, or individual responsibility and accountability for emissions resulting out of flight practice.

\section{Perspectives on the legitimacy of flight: moral concern and economic value}

Until 2018, public debate on the legitimacy of flight has been modest, though newspapers reported irregularly on the issue (e.g. Deutsche Welle 2018; USA Today 2018). In autumn 2018, the term 'flight shame' emerged in Sweden (Extrakt 2018) and rapidly spread worldwide (e.g. Evening Standard 2019). Flight shame identifies air travel as morally questionable (cf. Markowitz and Shariff 2012), hence raising the issue of the legitimacy of travel motivations. Hares et al. (2010) suggested that 'necessity' is not self-evident, as the climate implications of air travel may not be part of decision-making: in many countries, climate change remains a contested issue (e.g. Ballew et al., 2019; Lee et al., 2015), and environmental impacts of flying are of little or no concern to a significant share of air travellers (Alock et al. 2017; Cohen and Higham 2011; Hares et al. 2010; Hanna and Adams 2017). Reasons for this may be implied in notions of entitlement (Barr et al. 2010), social needs (Thurlow \& Jaworski 2006; GermannMolz 2012), or beliefs in future technology to resolve the issue (Peeters et al. 2016).

Yet there is evidence that significant variation lies in the value ascribed to air travel. Research among international tourists in New Zealand found that tourists distinguish "legitimate holidays" from "dispensable trips" (Becken 2007), though where and why boundary lines are drawn is unclear. Cohen and Higham (2011) established that a share of travellers show moral concern and even anguish over the consequences of their air travel, to the degree that they may decide to no longer fly, at least temporarily (Higham and Cohen 2011; see also Randles and Mander 2009). Similar findings were presented by Kroesen (2013) who affirms that air travellers consider flight by integrating environmental concerns (not flying or flying only in emergencies), ignorance (insufficiently informed about environmental outcomes), denial (climate is not changing), necessity (to perform work), guilt (inacceptable, but part of lifestyle), or indulgence/fatalism (lifestyle/too late anyway to act on climate change).

The deep moral conflicts in which some air travellers find themselves (Randles and Mander 2009) prompted Higham et al. (2014) to suggest that with growing awareness of climate impacts, air travel would be increasingly characterized by a "flyers dilemma", that is, a growing tension between desirable consumption patterns and climate concerns. Kantenbacher et al. (2017) expected that in the course of such events, any limitation of air travel would increasingly amount to 'sacrifice' in the form of foregone personal benefit. However, significant traveller 
numbers in Sweden voluntarily opted out of air travel as a result of flight shame, as measurable in an observed decline in passenger numbers (Bloomberg 2019). As a growing share of air travellers weigh the desirability of air travel against its moral legitimacy, social norms are beginning to be recast in the process, creating new perspectives on personal responsibility and accountability in flying decisions.

As Gardiner (2011) emphasized, the challenge of addressing climate change is ultimately ethical, and relates to the failure of political and economic systems to hold individuals accountable for their actions. Views of what is legitimate is again linked to behaviour in society as a whole, in the sense that the norms of social networks influence and guide individual actions (Gilovich and Griffin 2010). It is also for this reason that Ajzen (1985) distinguished attitudes from social norms; the former representing an individual's evaluation of the desirability of a given behaviour, the latter referring to the moral frameworks of society or peer groups. As both are interlinked, individual and societal views have relevance in the discussion of moral concern and social practice in the sphere of air travel consumption.

A second major perspective on flight is contained in the economic value ascribed to flight by individuals and society. Individual economic value perspectives are represented in market transactions, in the form of demand for air travel in relation to cost. This also means that consumption 'norms' are negotiated in terms of affordability, implying that if the cost of air travel was higher, this may not be considered a (forced) sacrifice (Kantenbacher et al. 2017), rather an economic reality. Indirectly, the findings presented by Kantenbacher et al. (ibid.: 10) support this proposition, because, as the authors conclude: "[...] on average, people have a greater willingness to give up leisure air travel than many other forms of consumption”.

Table 1 conceptualises dimensions and possible measures of moral concern and economic value in relation to flight, including both individual and societal perspectives. Individuals concerned about the implications of their flight activity may abstain from air travel. For example, Sweden's abovementioned decline in air traveller numbers, possibly as a result of flight shame debates (Bloomberg 2019). Likewise, an increase in voluntary carbon offset purchases would seem to reveal an increase in moral concern (Huber et al. 2018), given that offsets represent a personal cost for a benefit that accrues to society as a whole.

On the societal level, discussions on the environmental implications of flight and 'flight shame' have appeared in global media formats as diverse as The Guardian (2019) and Forbes (2019), bearing witness of an emerging social norm that is more critical of energy-intense consumption. Even though perhaps global for the first time in terms of media coverage, this is not necessarily a new view, as Randles and Mander (2009: 93) already reported on diverse perspectives of frequent flying a decade ago:

Accounts and justifications concerning frequent flying range from surprise that a taken-for-granted everyday activity which until very recently had been considered a culturally desirable thing to do, has suddenly become frowned upon; to a sense of almost guilty pleasure, apology and, at its extremes, defiance.

DEFRA (2009: 65), in the same year, reported in a study of UK citizens that $44 \%$ of respondents supported the view that "people who fly should bear the cost of the environmental damage that air travel causes”. Hares et al. (2010) however identified the lack of personal responsibility among air travellers as a major barrier to behavioural change (i.e., flying less). Contributors to climate change "were considered to be governments, businesses and other countries" (ibid.: 
471). Similar findings were presented for air travellers in Sweden, who considered themselves the least responsible for their flights, after aircraft producers, airlines, governments and intergovernmental organisations (Gössling et al. 2009b). This indicates diverging perspectives on responsibility between flying individuals and society at large, which may be measured in terms of the number and geographical distribution of shame debates, or societal views on accountability. Both would be representative of changes in social norms. It needs to be noted, however, that there also exist discourses regarding socially warranted forms of travel, such as contributions to biodiversity conservation, poverty reduction, or voluntary work (Fennell 1999; McCabe et al. 2012; Scheyvens 2011).

The economic value of flight could be measured, on the level of the individual, as the share of income placed on air travel, or their frequent flier status. Economic value perspectives would consequently measure 'desirable' air travel in relation to what is considered affordable. A general relationship, travel money budgets, was postulated by Zahavi (1974), and could be assessed for air travel: Surveys have generally found that air travellers are disproportionally wealthy (e.g. Banister 2018; Carlsson-Kanyama and Lindén 1999; Gössling et al. 2009b). Economic interrelationships have also been measured in price elasticity, denoting that an increase in price will result in a decrease in demand (Gillen et al. 2003). Price elasticity varies between traveller segments, in relation to distance, travel motive, and flight class (SIKA 2006), suggesting that the necessity of flight is contextual. Frequent flier status is another measure of economic value, in terms of the importance associated with flight activity and status class, for which additional trips will be made ("mileage runs"; Gössling and Nilsson 2010). On a broader societal level, the economic value of flight may be assessed on the basis of the value of subsidies extended to airlines, infrastructure providers or aircraft manufacturers (Gössling et al. 2017b), or the opposite, the existence and scale of taxes or air passenger duties placed on air travel (T\&E 2018). These are not necessarily representative, however, of public opinion on aviation's economic value.

Table 1: Measures of the importance of flight

\begin{tabular}{|l|l|l|}
\hline Perspective & Individual & Social \\
\hline Moral concern & $\begin{array}{l}\bullet \text { Reduction in flight activity } \\
\bullet\end{array}$ & $\begin{array}{l}\bullet \text { Chame debates } \\
\bullet \quad \text { Views on accountability }\end{array}$ \\
\hline Economic value & $\bullet \begin{array}{l}\text { Income to flight ratio } \\
\bullet\end{array}$ & $\begin{array}{l}\bullet \text { Frequent flier status } \\
\bullet\end{array}$ \\
\hline
\end{tabular}

To illustrate the wide range of perspectives on moral concern and economic value that may exist in relation to specific travel motivations, a number of examples are discussed in the following section.

\section{Motivations for flight}

Motivations for air travel are usually characterized as leisure, visiting friends and relatives (VFR), or business (UNWTO 2018). Leisure is generally considered to be the key drive of discretionary air travel, a category that includes motivations ranging from novelty seeking, escape, relaxation, relationship strengthening, autonomy, nature exploration, self-development, stimulation, self-actualisation, nostalgia, romance and recognition (Pearce and Lee 2005). VFR refers to any travel primarily related to maintaining social ties (e.g. Moscardo et al. 2000). Business travel can include meetings, conferences and conventions, exhibitions, training courses (and other forms of education), product launches, or incentive travel (Swarbrooke and 
Horner 2001). Any of these can involve very different actors, such as business travellers, government employees, NGO workers, military servicemen, students and teachers (ibid.). Business travel as defined in this article would also include that undertaken by athletes, singers and musicians. For many trips, however, travel motives may not fit any of these categories, or may blur across several of them (Hall 2005).

To illustrate the variation in reasons for flight in the context of what may constitute 'necessary' air travel, Table 2 lists a wide range of media reports on travel motives. Their choice is neither systematic nor representative, and serves the sole purpose of highlighting potentially controversial perspectives on the relevance or justification of different trips.

Table 2: Media headlines illustrating a diversity of reasons for air travel

\begin{tabular}{|l|l|}
\hline Reason & Reference \\
\hline S.99 million seat sale - cheap travel & Ryanair, 2018 \\
Shopping weekends - shopping & Lufthansa, 2019 \\
Stag parties - city break with friends & Stag Company, 2018 \\
(Mega)sport events - sports & New York Times, 2018 \\
Music performances - music & Daily Sabah, 2019 \\
Celebrity photographs - meeting celebrity & The Guardian, 2018 \\
Company-sponsored breaks - incentive trip & Dagbladet, 2018 \\
Diplomacy - politics & The Atlantic, 2013 \\
Political missions and campaign trails - politics & Samtiden, 2018; The Guardian, 2016 \\
Overseas educational trips - education & Stuff, 2018 \\
Protests and rallies - climate change protests & Mirror, 2019 \\
Pet transport - moving a dog in private aircraft & Financial Times ,2016 \\
Mileage runs - flying to earn points & CNN, 2018 \\
\hline
\end{tabular}

Cheap flight is a key sales argument used by low-cost carriers, with Irish airline Ryanair being known for campaigns in which "one million seats” are offered at a very low price (£9.99 in late 2018; Ryanair 2018). German Lufthansa advertises a three-night 'Christmas Shopping in New York' trip (Lufthansa 2019), while the Stag Company advertises 'flight experience stag weekends' (Stag Company 2018). Hundreds of thousands of spectators fly to see the Olympics (New York Times 2018). The 2019 Europa Cup final between two London clubs separated by eight miles (Arsenal and Chelsea) was played in Baku (Azerbaijan); a five-and-a-half-hour flight of 2860 miles ( $4600 \mathrm{~km}$ ) undertaken by tens of thousands of fans. Sport competitions and events at all levels of competition from school teams to global championships have very significant air travel demands (Higham \& Hinch, 2018). Music-related travel can involve singers, musicians, choirs or ensembles, sometimes travelling over vast distances (Daily Sabah 2019). The Guardian (2018), in highlighting an emerging problem for Korean Air, reports on K-pop fans booking flights to get close to their favourite band members, only to disembark again after having taken the photographs, and to then claim back the money paid for the tickets.

Business incentive travel is widespread. In January 2017, a group of 60 Norwegian plumbers on a flight from Oslo to Munich created media headlines because their aircraft had to return due to a faulty toilet - the group was on a company-sponsored short break (Dagbladet 2018). According to The Atlantic (2013), former Secretary of State Hillary Clinton had visited 112 countries in her four years in office, flying 956,733 miles (or 1.5 million km) for diplomatic and political missions. In Sweden, the question was discussed whether "politicians are worth to fly business class" (Samtiden 2018: no page), while politicians in Germany faced criticism for using governmental air services for private trips (Der Spiegel 2014). An outcry arose in 
New Zealand in 2017 when it as revealed that members of parliament received free international business class travel for themselves and their spouses for the rest of their lives at the taxpayer's expense (The Herald 2017). Overseas school educational trips are common in many western countries, and there is an array of opportunities for educational trips including short-term exchanges to gap year travel (Stuff 2018). Celebrities may fly to rallies to protest climate change (Mirror 2019). CEOs and business owners travel in private aircraft (Bloomberg 2018), sometimes using these to only fly their pets (Financial Times 2016). CNN (2018), in discussing "the art of the mileage run", reports that:

Paul Bevan flew from New York to Detroit to Tokyo to Singapore and back the same way without ever leaving an airport. The whole thing took 63 hours. Bevan says he "showered, ate a fabulous Indian meal at the food court at 3 a.m., mooched around a bit and flew back at 6 for 21,000 MQM's [Medallion Qualification Miles, the authors] and ensured making Diamond [a frequent flier status, the authors] again this year."

As the examples from media headlines illustrate, reasons for flight vary widely, as expressed in terms of the economic value associated with these trips. Often, this value is personal: for a less affluent person, using a subsidized flight offered by a low-cost carrier may be the only affordable form of air travel. For a wealthy individual, it may seem justified to fly home a favourite pet in a private aircraft. Yet, individual and societal views on the importance or desirability of these flight motives may vary, if moral concern is involved. In particular when the benefits associated with specific flights, such as mileage runs, accrue to the individual, negative implications for society may be weighed into considerations of desirability. Given complex views on the necessity and desirability of flight, an important question is also whether a considerable share of air travel is "induced", either through marketing campaigns, or offers of cheap flight. One way to further disentangle these interrelationships is to empirically evaluate ex post personal views on the perceived importance of air travel.

\section{Methodology}

A mixed method approach was used to examine perceptions of the importance of air travel, including a quantitative analysis of travel patterns of a sample of international students $(n=29)$, and an analysis of essays written by these students discussing 'flight importance'. Data was collected in September 2018 in a class of Service Management Master Programme students at Lund University, Sweden. Students were between 21 and 37 years, representing 24 different nationalities. The sample includes 14 male and 15 female students. This is a convenience sample, which was deemed acceptable given that this research only seeks to understand whether the importance placed on different flights varies; i.e., to test the general hypothesis that not all air travel is equally desirable or relevant. Data on individual flight activity in combination with information on flight purpose is generally unavailable, and difficult to obtain for frequent fliers (Gössling et al. 2017a). Whilst the sample size would normally not meet the criteria for statistical power, our statistical analysis was not concerned with within or between subject analysis of the participants, rather we took the flights $(n=587)$ as the unit of analysis.

In order to collect data on flight activity, students were asked to provide lists of their flights over the past six years (2012-2017), though depending on age or other factors, students may only have flown in 2017. To generate complete accounts, they were encouraged to recall trips on the basis of social media accounts (Facebook, Twitter, Instagram), and/or passport entry/exit stamps and visas. All flights had to be entered in a specifically designed Excel-file, detailing departure and arrival information. Flights had to be registered one by one, i.e. stopovers had to 
be considered. For example, a trip from Stockholm, Sweden to Brisbane, Australia, via Los Angeles, USA, would be registered as two flights: From Stockholm to Los Angeles, and from Los Angeles to Brisbane. If students had returned via different routes, this was registered separately. Travel over New Year was registered as a flight in the respective year; i.e., only the flight falling into a given year was registered in this year.

Once all flights had been identified, students were asked to calculate the distances flown, using the website www.greatcirclemapper.net. This will underestimate true flight distances by about $5 \%$, as detours, no-flight zones or other deviations from great circle distance are not included (UNWTO-UNEP-WMO 2008). Distances were then added up, to derive the total distances flown by each student. Once this was completed, students were asked to annotate the purpose of each flight in the Excel-file, using categories including VFR; trips home (to see family); business, work or study; leisure; religious purposes; sports; other (specify).

In a last step, students were asked to rate the relative importance of each flight, on a Likert Scale from 1 (very important flight) to 5 (flight having no importance at all). In order to understand how students had defined "importance", they were then asked to reflect on their understanding of the term in a personal essay. Essays were intended to confront students with their own travel decisions, and the desirability of different flights. This qualitative aspect of the research design served the purpose of better understanding and illustrating quantitative findings (Bryman 2016). Specifically, the discussion of less or more important flights added insights to the reasoning of students, while increasing the credibility of the conclusions drawn. Essays were evaluated using a structured approach to content analysis, in that comments regarding less important to very important flights were collected in a data file, and compared for the entire sample of students. This allowed examinations of links, and common as well as contradictory views. These are discussed in the form of a narrative, outlining important themes (ibid.).

The approach used in this study is different from earlier studies that have studied perceptions and attitudes (e.g. Cohen and Higham 2011; Higham and Cohen 2011) or measured intentions to reduce flight activity (e.g. Gatersleben et al. 2014; Morten et al. 2018). The assessment of ex post views on air travel allows for a more credible evaluation of personal views on the importance of flight, and thus complements these earlier studies. The data is however limited in that students enrolled in the Service Management programme at Lund University are not representative of any wider student population, or air travellers in general. Their views are necessarily indicative only. Data on flight activity is also conservative in the sense that most students participated in a great number of flights and thus some may have been overlooked.

\section{Results}

In total students $(n=29)$ recalled 587 flights that covered a total distance of 2.19 million kilometres, or an average of 75,413 km per student over the six-year period. Results indicate vast differences covered by individual students, of whom the least-travelled covered $864 \mathrm{~km}$, and the most frequent flier $320,901 \mathrm{~km}$. This is not necessarily a reflection of travel intensity per individual, as the periods covered depend on student age (20-37 years) and the number of years during which students had flown (2012-2017; that is one, and up to six years).

Most flights were registered for the year 2017. About one third (32\%; $n=187)$ of all flights were made in this year, covering a total distance of 549,645 km. This translates into an average of 9.4 flights per student, with a minimum of 1 flight (the return flight taking place in the following year), and a maximum of 15 flights (median: 6 flights). The average distance flown in 2017 
was 18,953 km, and ranged from $518 \mathrm{~km}$ to 46,836 km per student. Results thus indicate that the group of international students studied in this paper is composed of frequent fliers.

The students flew for a wide range of reasons, with "leisure" being the most frequently cited motive that accounts for 237 (40\%) of the 587 flights (Figure 1). VFR was the second most common reason ( $23 \% ; n=135)$ followed by education $(14 \% ; n=84)$, work $(11 \%$; $n=64)$, visits home $(3 \% ; n=19)$, to renew visa $(1 \% ; n=8)$ and to partake in or observe sports events $(1 \%$; $\mathrm{n}=5)$. Miscellaneous included $6 \%$ of trips $(\mathrm{n}=35)$, comprising, for example, religious motives. It should be noted that "visits home" refer to immediate family, in comparison to VFR travel to see friends or other relations.

A majority $(37 \% ; n=217)$ of flights were considered 'very important' and $21 \%(n=125)$ 'important' (Figure 2). Another 21\% of flights $(n=124)$ were judged neither important nor unimportant, while 13\% $(n=76)$ had 'limited importance', and $8 \%(n=45)$ had 'no importance at all'. Results thus suggest that one in five flights (21\%), i.e. those with no or limited importance, may be considered redundant.

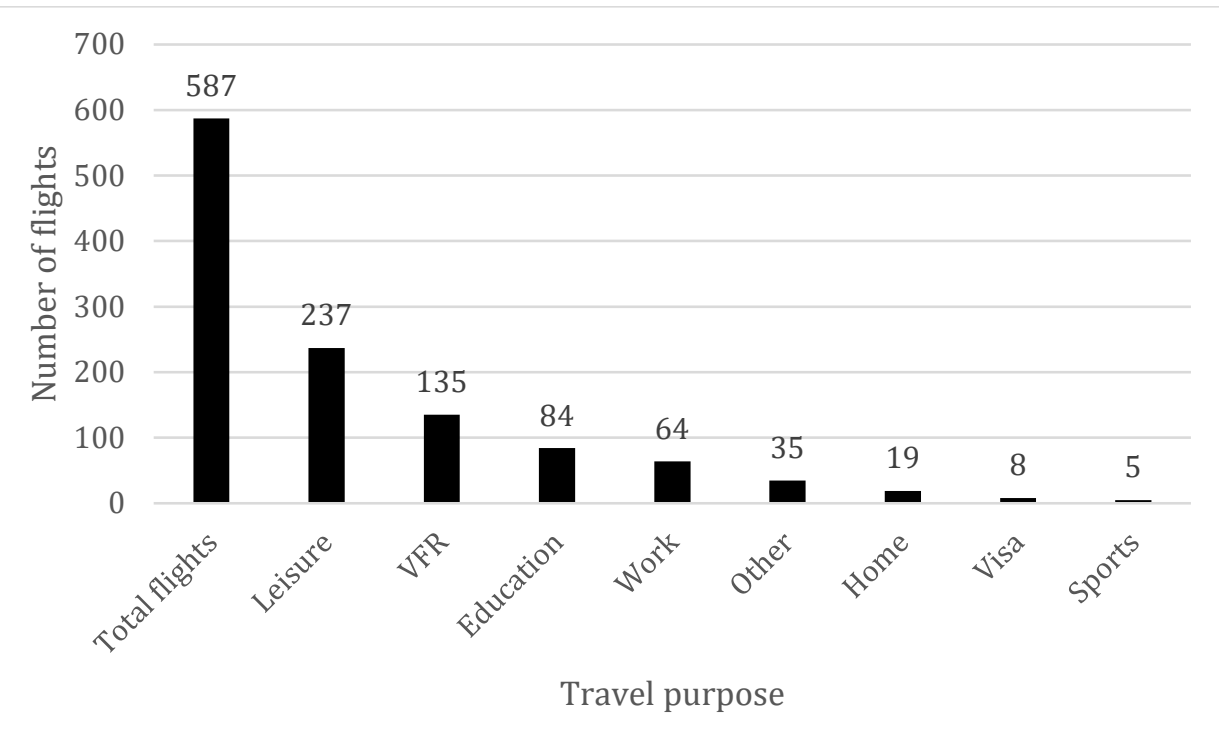

Figure 1: Travel purpose for flights

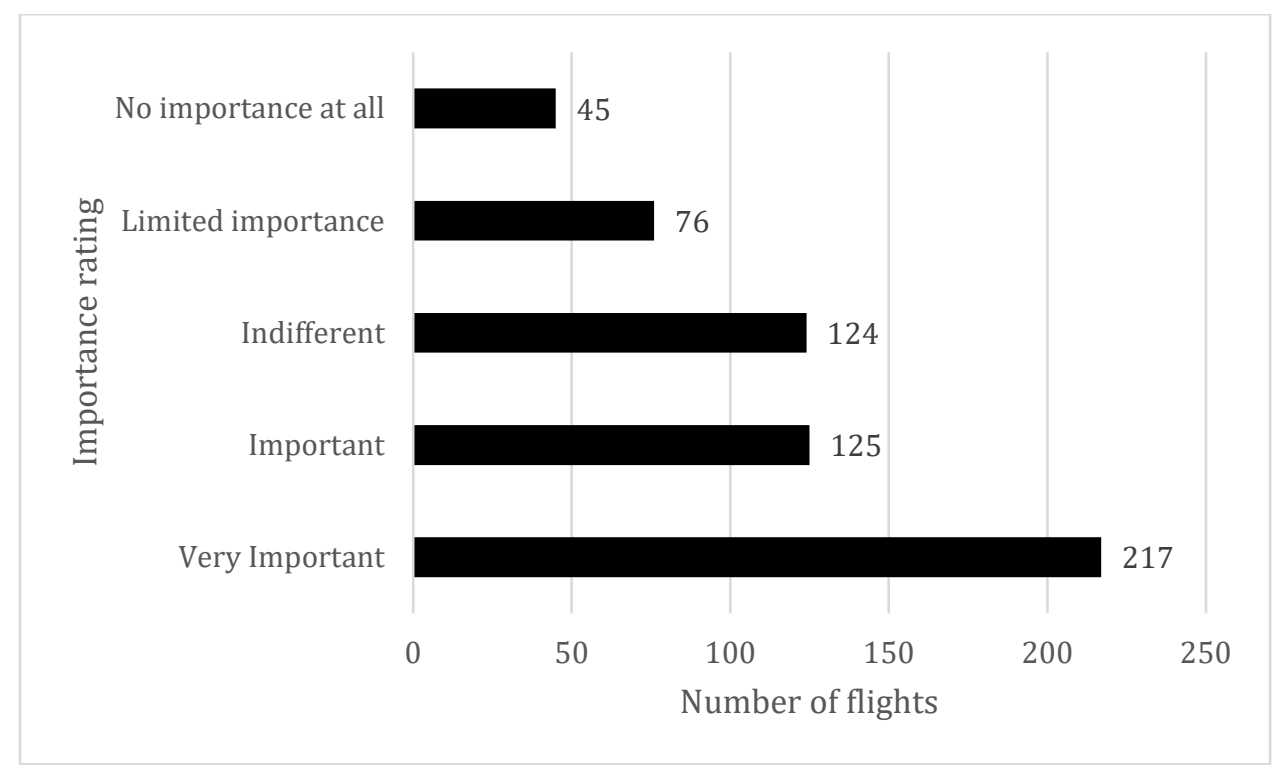




\section{Figure 2: Flight importance}

Figure 3 shows the analysis of flight distance by purpose, indicating that flights to visit friends and relatives have the highest mean average of 4,460 kilometres, though individuals also travel significant distances for educational purposes (mean $=4,325 \mathrm{~km}$ ). Participants in this study did not fly the furthest for leisure purposes, with the average distance for this type of trip being $3,218 \mathrm{~km}$. Trips home $(2,953 \mathrm{~km})$, for work $(2,519 \mathrm{~km})$ and for visa renewal $(2,244 \mathrm{~km})$ represented transport motives covering the shortest distances. When exploring the total flight distance (2.19 million kilometres) differences between the distance of the flight and the purpose of the trip were found to be statistically significant $(F(7,579)=2.500, p<0.05)$.

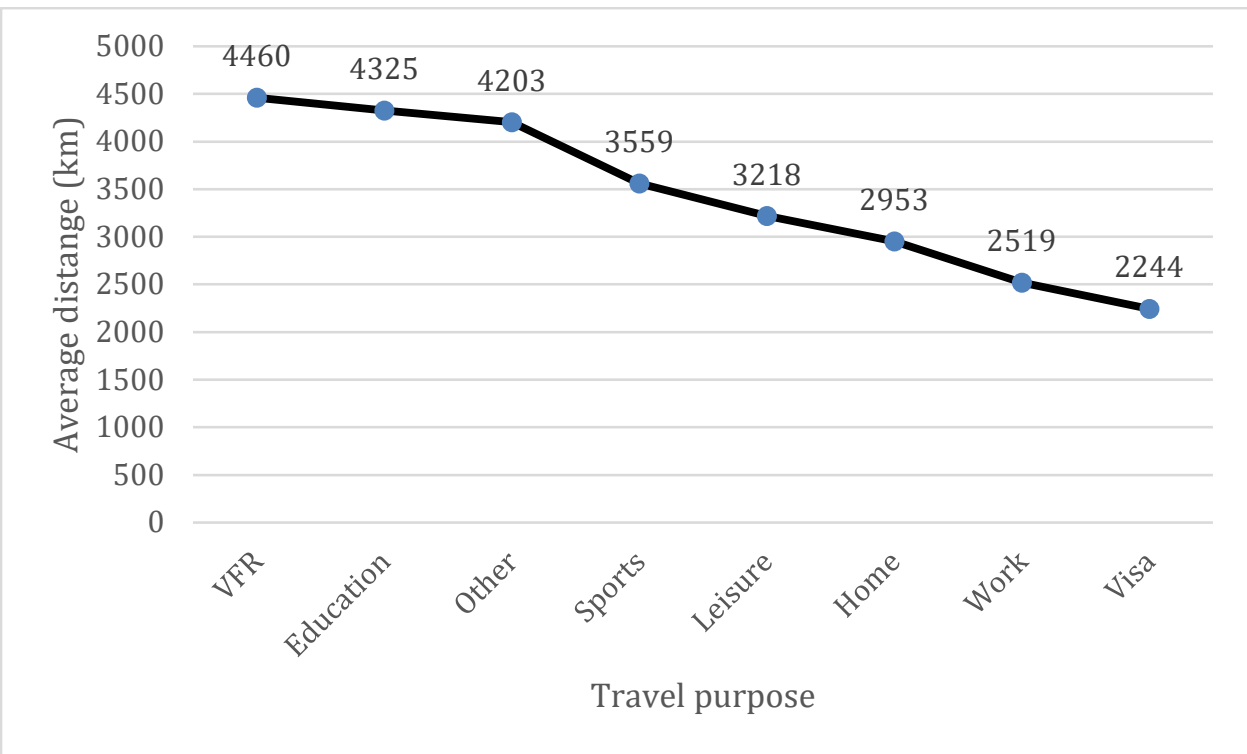

Figure 3: Flight distance by purpose

Figure 4 compares flight distance and importance ratings. This relationship tested statistically for the total distance travelled (2.19 million kilometres), with $F(4,582)=7.767, p<0.01$. The mean average distance of flights rated as 'very important' was 4,688 kilometres whereas the mean average was half that for flights rated as having 'no importance at all' (mean = 2,027 km). This suggests that the longer flights made by students have greater importance. This result would have been expected given that longer flights will on average also be more expensive, and may not be able to be replaced by other modes (e.g. high-speed rail). It also indicates a relationship between the importance of flight, VFR travel motives, flight distance, and willingness to pay for air travel. 


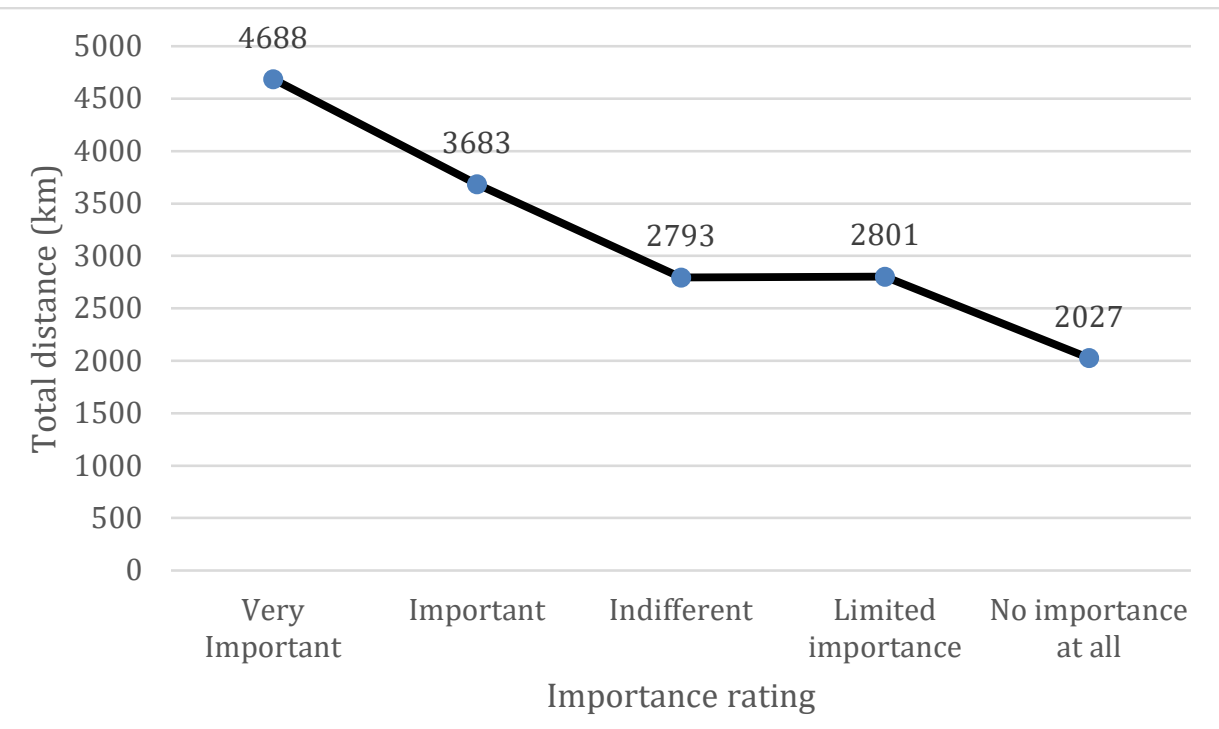

\section{Figure 4: Importance of flight by distance travelled}

Table 3 gives an account of the purpose for travel and its relative importance rating. Whilst there is a general mix in terms of each holiday purpose having some trips that are important and some that are not, the differences achieved statistical significance $(H(7)=65.842, p<0.01)$. For example, $52 \%$ of all leisure trips were rated as 'important' or 'very important' leaving the remaining $48 \%$ as lacking explicit importance (percentages are similar for VFR and work). Flights taken for the purpose of education was rated as the highest in terms of importance with $71 \%$ of flights for educational purposes being rated as 'very important' and a further $11 \%$ as 'important'. Flights taken for trips involving sport were rated as least important with $80 \%$ of all sports trips rated as 'no importance at all', however the number of sports trips was low across the data corpus. Typically, educational trips are longer in duration than sports trips, which in the vast majority of cases can be readily substituted by seeking competition that is less distant and does not require international or domestic air travel (Higham and Hinch 2018).

Table 3: Travel purpose and flight importance

\begin{tabular}{|ll|l|l|l|l|l|l|l|}
\hline & Leisure & VFR & Education & Work & Home & Visa & Sports & Other \\
\hline Very Important & $51(21.5 \%)$ & $50(37 \%)$ & $60(71.4 \%)$ & $18(28.1 \%)$ & $11(57.9 \%)$ & $3(37.5 \%)$ & $1(20 \%)$ & $23(65.7 \%)$ \\
\hline Important & $72(30.4 \%)$ & $20(14.8 \%)$ & $9(10.7 \%)$ & $13(20.3 \%)$ & $1(5.3 \%)$ & $3(37.5 \%)$ & 0 & $7(20 \%)$ \\
\hline Indifferent & $58(24.5 \%)$ & $40(29.6 \%)$ & $4(4.8 \%)$ & $13(20.3 \%)$ & $4(21.1 \%)$ & 0 & 0 & $5(14.3 \%)$ \\
\hline $\begin{array}{l}\text { Limited } \\
\text { importance }\end{array}$ & $41(17.3 \%)$ & $17(12.6 \%)$ & $1(1.2 \%)$ & $16(25 \%)$ & $1(5.3 \%)$ & 0 & 0 & 0 \\
\hline $\begin{array}{l}\text { No importance } \\
\text { at all }\end{array}$ & $15(6.3 \%)$ & $8(5.9 \%)$ & $10(11.9 \%)$ & $4(6.3 \%)$ & $2(10.5 \%)$ & $2(25 \%)$ & $4(80 \%)$ & 0 \\
\hline
\end{tabular}

These results can be compared to qualitative data from the essays. First of all, students agreed that 'importance' is subjective, implying different things for the individual, such as opportunities for personal development, unique experiences, the achievement of life goals, or specific situations of relevance such as the wish to see family. As air travel was assessed in retrospective, views imply that students evaluated what they would have 'missed' had they not made the flight. Students also agreed that perspectives are comparative, in that they weigh different trips and travel purposes over the entire range of trips made by air in their lives. From 
the discussion it also emerged that views on 'importance' are evolving, in that they change with the frequency of flight as well as the overall number of flights made.

The discussion of the importance of trips revealed that social (visits at home, VFR) and educational motivations had great importance for students. Notably, the first flight ever made, and in particular the first intercontinental flight, was mentioned as having great importance, as signifying new opportunities to visit other countries and cultures. As the sample addressed international students, who often stay for extended periods in Sweden, going home for special (social) events or holidays had great importance. Likewise, to maintain relations with friends was mentioned as an important reason for air travel. Very important trips are also those related to studies, for a term abroad, and writing Bachelor or Master theses, as studies are considered as having great relevance for personal and professional development. This implies that with growing opportunities for working or studying abroad, these very important travel motives will increase.

Important trips are also linked to leisure travel. Students highlighted that getting out of daily routines, to take a break, to encounter new values and cultures was important to expand worldviews and to appreciate personal lives and origins. Students also mentioned decisions to travel to 'must see' destinations, which may be influenced by social media, though this could result in high expectations that were not met. A relevant finding in this context is that destinations become less important once visited: as an example, the second trip to Paris is considerably less important than the first. More generally, less important trips included those planned by others, or trips where the destination had not been a personal choice. Negative experiences, such as adverse weather conditions, unfortunate social or professional encounters in the destination, or illness also resulted in a decline in trip value. Lower importance was also placed on trips to closer destinations, as well as 'assigned' business trips. The latter were considered less desirable when they had negative outcomes, or perceived as not relevant enough to motivate travel.

In their essays, students confirmed that had they not made flights with no or limited importance, it would not have mattered to them. Partially, such trips were only made because of their low cost, with students reporting that they often hunted for bargains. Cheaper connections also influenced flight decisions with regard to timing (day time, date), travel time (time needed to arrive at destination), as well as destination choice. Essays also revealed that air travel was favoured over other transport modes (such as trains) because of cost considerations. Yet, students did not feel that restrictions in air travel, such as rising cost, would affect them negatively, as they believed they could adjust. For example, the growing high-speed railway system in China and the growing number of long-distance low-cost bus connections in Europe were mentioned as alternatives. For business travel, students suggested that most meetings could have as easily been held as a video-conference, or by phone call. As the relevance of trips can often only be assessed after the trip, it may however be difficult to establish the importance of a given flight in advance.

Finally, students distinguished "compulsory" and "spontaneous" trips. Compulsory travel cannot be avoided, including for example trips to renew a visa. Spontaneous trips are associated with a higher cost, and they had to be more carefully justified. The need for such trips may arise out of specific situations, such as a case of illness or death among friends or relatives.

\section{Discussion}


The purpose of this paper was to discuss whether all flight is 'necessary' or 'desirable', as often purported by airlines and aviation organisations that prefer to leave the desirability of air travel unquestioned. Various authors have indirectly taken up this question. For instance, Randles and Mander (2009) as well as Dickinson et al. (2010) showed that air travel co-evolves within the structures provided by society, in which the cost of flying is a key determinant. The implication is that where the price is low, air travel demand will grow: for instance, as a result of various forms of subsidies extended to airlines, aircraft manufacturers or airports. Hares et al. (2010) thus concluded that economic instruments and regulatory controls are needed to reduce emissions from air travel. These are however difficult to implement given perspectives on entitlement to air travel (Higham et al. 2016), while also having to be significant in order to be effective (Markham et al. 2018).

The discussion in this paper adds that attitudes and social norms also have important implications for behaviour. While most studies concluded that air travellers will not fly less because of moral concerns (Alcock et al. 2017; Becken 2007; Cohen and Higham 2011; Dickinson et al. 2010; Hares et al. 2010; Hanna and Adams 2017; Randles and Mander 2009), it seems clear that this can change when wider social norms change. In the past, moral concerns have been deflected by assigning responsibility to others, including governments, airlines, or aircraft manufacturers (Gössling et al. 2009b; Hares et al. 2010). With emergent debates on flight shame, it seems increasingly difficult to maintain this viewpoint. Specifically, media interventions of Swedish student Greta Thunberg, Swedish athlete Björn Ferry, or British academic Kevin Anderson, who all refuse to fly, have changed perspectives on personal accountability. For example, Morten et al. (2018: 303) affirm that individuals with more positive attitudes towards reducing flight activity and who also believe that important others would want them to fly less are more likely to intend to reduce their own flight numbers. In contrast, where mechanisms of denial for accepting responsibility persist, there is a conflict between self-interest and common good, in which changing one's own behavior is not an option when others continue their unsustainable activities (Hares et al. 2010).

This contradicts notions that fostering awareness of air travel's climate impacts is largely superfluous (Alcock et al. 2017); rather, it confirms that supporting moral concern is key to changing social norms that will also build pressure on lawmakers to implement low-carbon policies for aviation. Notably, in countries where moral concern is more developed and trust in government high, it will be easier to justify and introduce such policies (Higham et al. 2016). A conclusion is thus that where moral concern and social norms co-evolve, this can affect both social practices and policy support for interventions. Current debates on flight shame and the justification of specific motivations for flight should thus be seen as supportive of changes in social norms.

Further insights can be gained from the empirical study presented in this paper. Findings suggest that the sample of international students consists of frequent fliers, with few exceptions. Students fly for a wide range of reasons, though in retrospective, they considered almost half of all flights (48\%) as "indifferent", "not important at all” or "of limited importance”. These less desirable flights are generally shorter in terms of the distance flown, and related to sports, work, visa, as well as leisure. For these trip motives, more than $25 \%$ were considered redundant. Very important trips include education (71\%), travel home (58\%), and VFR (37\%). While trips to renew a visa are also considered very important by a significant share of students (38\%), this is not necessarily a contradiction to visa-related trips considered redundant, as visas are both a necessary precondition for international trips and in particular education. Students may have had difficulties in aligning personal wants with institutional needs, when deliberating the 
importance of flight for visa renewal. These findings affirm that the 'necessity' or desirability of air travel varies with trip purpose, also confirming that leisure or VFR related flights should not per se be seen as "more superfluous and readily avoidable" than business flights widely considered outside the individual's control (Morten et al. 2018).

Student essays also confirmed that economic reasoning underpins most travel decisions (timing, length of stay), as well as travel motivations (whether to travel in the first place). Cost will thus determine whether a flight is relevant, suggesting that studies of price elasticity (Gillen et al. 2003) need to pay greater attention to motivations. The findings presented in this paper underline that under scenarios of significant cost increases for air travel, a large share of air travel is likely to simply disappear, in an analogue with congestion charges. For example, in a study of the effects of the Stockholm city charge, Eliasson (2014: 85) concluded that even though there was a significant decline in traffic, a three-quarter share of the shunned car trips "seems to have gone unnoticed by the travellers themselves" in the sense that respondents did not recall changes in transport behaviour.

It is evident that views on 'necessary' flight can be framed by economic value and moral concern, and that perspectives will vary between individuals, between individual and society, and between societies, with the value associated with flights varying depending on motive, experience, life stage and other situational factors. There is evidence that discourses of cheap flight and entitlement to air travel as created by airlines and aviation organisations support social norms that are not aligned and, indeed, fundamentally at odds with the low-carbon challenge. Discourses also contribute to a culture of deniability, even though any society interested in reducing emissions should foster personal accountability and moral concern. Policymakers should be aware of these interrelationships, and support critical debate on aviation, while resisting and perhaps ultimately restricting indoctrination by the aviation system.

\section{Conclusions}

Currently questions of the necessity of air travel are conveniently ignored, or actively resisted by the vast majority of air travellers in the current socio-technical and dominant neoliberal economic systems, which prioritise and encourage excessive air travel (Young et al. 2014). The need to fly cannot remain unquestioned in a situation with pressing timeframes for emission reductions (IPCC 2018). This paper asked active air travellers confronting questions of the necessity of air travel. It shed light on how air travel is valued, and revealed heterogeneous justifications and perceived necessities for different types of travel, revealing that types and purposes of air travel are not equal. Rather the importance of air travel depends on a wide variety of factors which include, but are not limited to, the purpose of travel, the distance and availability of alternatives, and other societal features including prestige. Notably, much air travel is induced by its low cost.

The research suggests that in order to reduce the carbon dependency of the transport system, and air travel-related emissions in particular, immediate steps should be taken to reduce superfluous air travel which is deemed by the traveller to be 'unnecessary'. To this end, ensuring that the cost of flight includes the environmental costs of flying should be an important and immediate priority, a point noted and accepted by air travellers in earlier research (Higham and Cohen 2011). An important insight emerging from this paper is that flying for social purposes such as VFR, or visits home, and for educational reasons, is likely to be relatively price inelastic and to endure even while many other flights may 'disappear' in the context of stronger policies to curb aviation demand. 
It must be noted that this paper represents an initial foray into an aspect of consumer culture and freedom to consume that will be resisted by many and fiercely opposed by some. It is important to extend this urgent line of enquiry to achieve detailed insights into how perspectives vary between individuals, between individual and society, and between societies.

\section{References}

Ajzen, I. (1985). From Intentions to Actions: A Theory of Planned Behavior. In Action Control: From Cognition to Behavior, edited by J. Kuhl and J. Beckmann. Berlin, Springer, pp. 11-39.

Alcock, I., White, M.P., Taylor, T., Coldwell, D.F., Gribble, M.O., Evans, K.L., Corner, A., Vardoulakis, S. \& Fleming, L.E. (2017). 'Green' on the ground but not in the air: Proenvironmental attitudes are related to household behaviours but not discretionary air travel. Global Environmental Change, 42, 136-147.

Ballew, M. T., Leiserowitz, A., Roser-Renouf, C., Rosenthal, S. A., Kotcher, J. E., Marlon, J. R., Lyon, E., Goldberg, M. H., \& Maibach, E. W. (2019). Climate Change in the American Mind: Data, tools, and trends. Environment: Science and Policy for Sustainable Development, 61(3), 4-18. doi: 10.1080/00139157.2019.1589300

Banister, D. (2018). Inequality in Transport. Alexandrine Press, Oxfordshire.

Barr, S., Shaw, G., Coles, T., \& Prillwitz, J. (2010). 'A holiday is a holiday’: practicing sustainability, home and away. Journal of Transport Geography, 18(3), 474-481.

Becken, S. (2007). Tourists' Perception of International Air Travel's Impact on the Global Climate and Potential Climate Change Policies. Journal of Sustainable Tourism, 15, 351-368.

Bloomberg (2018). Keeping Zuckerberg Safe Now Costs an Extra \$10 Million a Year. Available: $\quad$ https://www.bloomberg.com/news/articles/2018-08-02/protecting-markzuckerberg-just-got-more-expensive-for-facebook Accessed 5 December 2018.

Bloomberg (2019). As 'Flying Shame' Grips Sweden, SAS Ups Stakes in Climate Battle. Available: $\quad$ https://www.bloomberg.com/news/articles/2019-04-14/as-flying-shame-gripssweden-sas-ups-stakes-in-climate-battle Accessed 26 April 2019.

Brand, C., \& Boardman, B. (2008). Taming of the few-The unequal distribution of greenhouse gas emissions from personal travel in the UK. Energy Policy, 36(1), 224-238.

Bryman, A. (2016). Social research methods. Oxford, Oxford University Press.

Carlsson-Kanyama, A., \& Linden, A. L. (1999). Travel patterns and environmental effects now and in the future: implications of differences in energy consumption among socioeconomic groups. Ecological Economics, 30(3), 405-417.

CNN (2018). Want airlines to treat you well? Do this. Available:

https://edition.cnn.com/travel/article/delta-diamond-status-mileage-run/index.html Accessed 6 March 2019

Cohen, S. A., \& Higham, J. E. (2011). Eyes wide shut? UK consumer perceptions on aviation climate impacts and travel decisions to New Zealand. Current Issues in Tourism, 14(4), 323335.

Dagbladet (2018). Do-drama på vei til München. Norwegian-fly måtte snu og sirkle. https://www.dagbladet.no/nyheter/do-drama-pa-vei-til-mnchen-norwegian-fly-matte-snu-ogsirkle/69383834 30 November 2018. 
Daily Sabah (2019). Russia’s Red Army Choir to give free concerts in Istanbul. Available: https://www.dailysabah.com/events/2019/03/05/russias-red-army-choir-to-give-free-concertsin-istanbul Accessed 7 March 2019.

DEFRA (2009). Public attitudes and behaviours towards the environment - tracker survey. Available:

https://webarchive.nationalarchives.gov.uk/20130124043058/http://www.defra.gov.uk/statisti cs/files/report-attitudes-behaviours2009.pdf Accessed 5 March 2019

Der Spiegel (2014). Erst geflogen, dann geflogen. Available:

http://www.spiegel.de/wirtschaft/flug-affaeren-von-politikern-und-managern-von-scharpingbis-suessmuth-a-945403.html Accessed 6 March 2019.

Deutsche Welle (2018). To fly or not to fly? The environmental cost of air travel. Available: https://www.dw.com/en/to-fly-or-not-to-fly-the-environmental-cost-of-air-travel/a-42090155 Accessed 19 May 2019

Dickinson, J. E., Robbins, D., \& Lumsdon, L. (2010). Holiday travel discourses and climate change. Journal of Transport Geography, 18(3), 482-489.

Eliasson, J. (2014). The role of attitude structures, direct experience and reframing for the success of congestion pricing. Transportation Research Part A: Policy and Practice 67, 81-95. Evening Standard (2019). How flygskam (or flight shame) is spreading across Europe. Available: https://www.standard.co.uk/lifestyle/esmagazine/flight-shame-europe-swedena4120231.html Accessed 25 April 2019.

Extrakt (2018). Flygskam minskar inte resandet. Available: https://www.extrakt.se/flygskamminskar-inte-resandet/ Accessed 25 April 2019.

Fennell, D. (1999). Ecotourism. London: Routledge.

Finance and Trade Watch (2016). The illusion of green flying. Available: https://www.ftwatch.at/flying_green/ Accessed 5 March 2019.

Financial Times (2016). Executive perks: The corporate jet files. Available: https://ig.ft.com/sites/business-jets/ Accessed 29 November 2018.

Forbes (2019). Will 'Flygskam' (Or Flight Shame) Be The Buzzword Of This Year's Summer Holiday? Available: https://www.forbes.com/sites/davidebanis/2019/04/26/will-flygskam-orflight-shame-be-the-buzzword-of-this-years-summer-holiday/\#796b72246d8d Accessed 5

May 2019.

Gardiner, S. M. (2011). A perfect moral storm: the ethical tragedy of climate change. Oxford University Press.

Gatersleben, B., Murtagh, N., \& Abrahamse, W. (2014). Values, identity and proenvironmental behaviour. Contemporary Social Science, 9(4), 374-392.

Germann-Molz, J. G. (2012). Travel connections: Tourism, technology and togetherness in a mobile world. London: Routledge.

Gillen, D.W., Morrison, W.G., Stewart, C., (2003). Air Travel Demand Elasticities: Concepts, Issues and Measurement. Department of Finance, Government of Canada. Available at: https://www.fin.gc.ca/consultresp/Airtravel/airtravStdy_-eng.asp Accessed 21 January 2019.

Gilovich, T.D. \& Griffin, D.W. (2010). Judgment and decision making. In: Fiske, S.T., Gilbert, D.T., Lindzey, G. (Eds.), Handbook of Social Psychology, vol. 1. fifth ed. McGraw-Hill, New York, pp. 542-589. 
Gössling, S., \& Upham, P. (Eds) (2009). Climate change and aviation: Issues, challenges and solutions. London: Routledge.

Gössling, S. and Nilsson, J.H. (2010). Frequent Flyer Programmes and the Reproduction of Mobility. Environment and Planning A, 42: 241-252.

Gössling, S., \& Stavrinidi, I. (2016). Social networking, mobilities, and the rise of liquid identities. Mobilities, 11(5), 723-743.

Gössling, S., Ceron, J. P., Dubois, G., \& Hall, C. M. (2009a). Hypermobile travellers. In S. Gössling \& P. Upham (Eds.), Climate change and aviation: Issues, challenges and solutions (pp. 131-150). London: Earthscan.

Gössling, S., Fichert, F. and Forsyth, P. (2017b). Subsidies in aviation. Sustainability, 9(8), 1295.

Gössling, S., Lohmann, M., Grimm, B., \& Scott, D. (2017a). Leisure travel distribution patterns of Germans: Insights for climate policy. Case Studies on Transport Policy, 5(4), 596-603.

Gössling, S., Hultman, J., Haglund, L, Källgren, H. And Revahl, M. (2009b). Voluntary carbon offsetting by Swedish Air Travellers: Towards the Co-creation of Environmental Value? Current Issues in Tourism, 12(1): 1-19.

Gretzel, U. (2017). \#travelselfie: a netnographic study of travel identity communicated via Instagram. In Carson, S. \& Pennings, M. (Eds.), Performing Cultural Tourism: Communities, Tourists and Creative Practices, pp. 115-128. New York: Routledge.

Gretzel, U. (2018). Influencer marketing in travel and tourism. In Sigala, M. \& Gretzel, U. (Eds.), Advances in Social Media for Travel, Tourism and Hospitality: New Perspectives, Practice and Cases, pp. 147-156. New York: Routledge.

Hall, C. M. (2005). Tourism: Rethinking the social science of mobility. Harlow: Pearson Education.

Hanna, P., \& Adams, M. (2017). Positive self-representations, sustainability and socially organised denial in UK tourists: Discursive barriers to a sustainable transport future. Journal of Sustainable Tourism, 1-18.

Hares, A., Dickinson, J., \& Wilkes, K. (2010). Climate change and the air travel decisions of UK tourists. Journal of Transport Geography, 18(3), 466-473.

Higham, J. E., \& Cohen, S. A. (2011). Canary in the coalmine: Norwegian attitudes towards climate change and extreme long-haul air travel to Aotearoa/New Zealand. Tourism Management, 32(1), 98-105.

Higham, J., Cohen, S. A., Cavaliere, C. T., Reis, A., \& Finkler, W. (2016). Climate change, tourist air travel and radical emissions reduction. Journal of Cleaner Production, 111, 336347.

Higham, J.E.S. \& Hinch, T.D. (2018). Sport Tourism Development (Edition 3). Bristol: Channel View Publications.

Higham, J.E.S., Cohen, S.A. \& Cavaliere, C.T. (2014). Climate change, discretionary air travel and the 'flyers' dilemma'. Journal of Travel Research, 53(4), 462-475.

Huber, R. A., Anderson, B., \& Bernauer, T. (2018). Can social norm interventions promote voluntary pro environmental action?. Environmental Science \& Policy, 89, 231-246. 
IATA (International Air Travel Association) (2018). Traveler numbers reach new heights. Press release, 6 September 2018. Available: https://www.iata.org/pressroom/pr/Pages/2018-09-0601.aspx Accessed 4 March 2019.

ICAO (International Civil Aviation Organization) (2016). 2016 Environmental Report. www.icao.int/environmental-protection/Pages/env2016.aspx

IPCC (Intergovernmental Panel on Climate Change) (2018). Special Report on Global Warming of $1.5^{\circ} \mathrm{C}$. Available: http://www.ipcc.ch/report/sr15/ Accessed 7 March 2019.

Kantenbacher, J., Hanna, P., Miller, G., Scarles, C., \& Yang, J. (2017). Consumer priorities: what would people sacrifice in order to fly on holidays?. Journal of Sustainable Tourism, 116.

Kroesen, M. (2013). Exploring people's viewpoints on air travel and climate change: understanding inconsistencies. Journal of Sustainable Tourism, 21(2), 271-290.

Lassen, C. (2006). Aeromobility and work. Environment and Planning A 38: 301-12.

Lee, T.M., Markowitz, E.M., Howe, P.D., Ko, C-Y., Leiserowitz, A.A. (2015). Predictors of public climate change awareness and risk perception around the World, Nature Climate Change, 5, 1014-1020. DOI: https://doi.org/10.1038/nclimate2728

Lufthansa (2019). Christmas Shopping in New York. Available: https://www.lufthansaholidays.com/en-de/christmas-shopping-in-new-york Accessed 7 March 2019.

Lyle, C. (2018). Beyond the ICAO’s CORSIA: Towards a More Climatically Effective Strategy for Mitigation of Civil-Aviation Emissions. Climate Law, 8(1-2), 104-127.

Markham, F., Young, M., Reis, A., \& Higham, J.E.S. (2018). Does carbon pricing reduce air travel? Evidence from the Australian 'Clean Energy Future' policy, July 2012 to June 2014. Journal of Transport Geography, 70, 206-214.

McCabe, S., Minnaert, L., \& Diekmann, A. (2012). Social tourism in Europe. Bristol: Channel View.

Mirror 2019. Emma Thompson joins climate change protest - after hopping on 5,400-mile flight. Available: https://www.mirror.co.uk/3am/celebrity-news/emma-thompson-joinsclimate-change-14431549 Accessed 5 May 2019.

Morten, A., Gatersleben, B., \& Jessop, D. C. (2018). Staying grounded? Applying the theory of planned behaviour to explore motivations to reduce air travel. Transportation Research Part F: Traffic Psychology and Behaviour, 55, 297-305.

Moscardo, G., Pearce, P., Morrison, A., Green, D., \& O’Leary, J. T. (2000). Developing a typology for understanding visiting friends and relatives markets. Journal of Travel Research, 38(3), 251-259.

New York Times (2018). How to Plan a Last-Minute Trip to the 2018 Winter Olympics in Pyeongchang. Available: https://www.nytimes.com/2018/01/17/travel/winter-olympics-tripplanning.html Accessed 6 March 2019.

Ostrowski, P. L., O'Brien, T. V., \& Gordon, G. L. (1993). Service quality and customer loyalty in the commercial airline industry. Journal of Travel Research, 32(2), 16-24. 
Oxfam (2015). Extreme Carbon Inequality. Available: https://www-cdn.oxfam.org/s3fspublic/file_attachments/mb-extreme-carbon-inequality-021215-en.pdf Accessed 25 April 2019.

Pearce, P. L., \& Lee, U. I. (2005). Developing the travel career approach to tourist motivation. Journal of Travel Research, 43(3), 226-237.

Peeters, P., Gössling, S. and Becken, S. (2006). Innovation towards tourism sustainability: climate change and aviation. International Journal of Innovation and Sustainable Development, 1(3): 184-200.

Peeters, P., Higham, J., Kutzner, D., Cohen, S. and Gössling, S. (2016). Are technology myths stalling aviation climate policy? Transportation Research Part D, 44: 30-42.

Randles, S and Mander, S. (2009). Aviation, consumption and the climate change debate: "Are you going to tell me off for flying?” Technology Analysis \& Strategic Management, 21(1): 93113

Ryanair (2018). Ryanair Launches Massive 24 Hour “Million-Air” Sale 1 Million Seats For Just £9.99 Available: https://corporate.ryanair.com/news/ryanair-launches-massive-24-hourmillion-air-sale-1-million-seats-for-just-9-99/ Accessed 6 March 2019

Samtiden (2018). Är politiker värda att åka business class. Available: https://samtiden.nu/2018/08/ar-politiker-varda-att-aka-business-class/ Accessed 7 March 2018.

Schafer, A. and Victor, D. G. (2000). The future mobility of the world population, Transportation Research - A 34: 171-205.

Scheyvens, R. (2011). Tourism and poverty. London: Routledge.

Scott, D., Hall, C. M., \& Gössling, S. (2016). A report on the Paris Climate Change Agreement and its implications for tourism: Why we will always have Paris. Journal of Sustainable Tourism, 24(7), 933-948.

Sheller, M. (2016). Uneven Mobility Futures: A Foucauldian Approach. Mobilities 11(1): 1531.

SIKA (Statens Institut för Kommunikatsionsanalys) (2006). Flygskattens effekter. Available: http://www.sika-institute.se?Doclib/Import/106/pm_2006_2.pdf Accessed 6 March 2019.

Stag Company (2018). Flight Experience Stag Dos. Available: https://www.thestagcompany.com/flight-experience-stag-weekends Accessed 4 March 2019.

Stuff (2018). Overseas school trips are pure luxuries. Available: https://www.stuff.co.nz/business/money/101762853/opinion-overseas-school-trips-are-pureluxuries Accessed 6 March 2019.

Swarbrooke, J. and Horner, S. (2001). Business Travel and Tourism. Oxford: Butterworth Heinemann.

T\&E (2018). Taxing aviation fuels in the EU. Available: https://www.transportenvironment.org/sites/te/files/publications/2019_02_CE_Delft_Taxing_ Aviation_Fuels_EU.pdf Accessed 7 June 2019. 
The Atlantic (2013). Hillary Clinton Travelled 956,733 Miles During Her Time as Secretary of State. Available: https://www.theatlantic.com/politics/archive/2013/01/hillary-clintontraveled-956-733-miles-during-her-time-as-secretary-of-state/272656/ Accessed 26 November 2018.

The Guardian (2018). Boarding on obsession: K-pop fans 'falsely' check in on flights to glimpse stars. Available: https://www.theguardian.com/music/2018/dec/19/boarding-onobsession-k-pop-fans-falsely-check-in-on-flights-to-glimpse-stars Accessed 19 December $\underline{2018}$

The Guardian (2019). John Vidal: Why I only take one holiday flight a year. https://www.theguardian.com/travel/2019/jan/26/why-i-only-take-one-holiday-flight-a-yearclimate-change Accessed 8 April 2019.

The Herald (2017). Former MPs and their perks - salary, free travel and taxpayer-funded cars https://www.nzherald.co.nz/nz/news/article.cfm?c_id=1\&objectid=11927540. Accessed 6 June 2019.

The Independent (2017). 'Instagrammability’: Most important factor for millennials on choosing holiday destination. Available:

https://www.independent.co.uk/travel/instagrammability-holiday-factor-millenials-holidaydestination-choosing-travel-social-media-photos-a7648706.html Accessed 3 May 2019.

Thurlow, C., Jaworski, A. (2006). The alchemy of the upwardly mobile: symbolic capital and the stylization of elites in frequent-flyer programmes. Discourse and Society 17 (1), 99-135.

Toh, R. S., Rivers, M. J., \& Withiam, G. (1991). Frequent-guest programs: Do they fly?. Cornell Hotel and Restaurant Administration Quarterly, 32(2), 46-52.

UN (United Nations) (2015). Sustainable Development Goals. Verfügbar: https://www.un.org/sustainabledevelopment/sustainable-development-goals/

UNWTO (2018). Tourism Highlights 2018. UNWTO: Madrid. Available: https://www.eunwto.org/doi/book/10.18111/9789284419876 Accessed 4 March 2018.

UNWTO-UNEP-WMO (UN World Tourism Organisation, United Nations Environment Programme, World Meteorological Organization) (2008). Climate Change and Tourism: Responding to Global Challenges. UNWTO, Madrid.

Urry, J. 2011. Social Networks, Mobile Lives and Social Inequalities. Journal of Transport Geography 21: 24-30.

USA Today (2018). Flying is bad for the environment, here are some tips to make it less carbon-intensive. Available: https://eu.usatoday.com/story/news/2018/12/26/flying-badenvironment-heres-what-do/2350488002/ Accessed 19 May 2019.

Young, M., Higham, J. E., \& Reis, A. C. (2014). 'Up in the air': A conceptual critique of flying addiction. Annals of Tourism Research, 49, 51-64. 
Zahavi, Y. (1974). Travel time Budgets and Mobility in Urban Areas. Department of Transportation, Washington, DC. 